\title{
Blessed Michael Sopocko: A Closer Look at the Mystery of Divine Mercy
}

Divine Mercy is that which ensures human happiness. In the 20th century, BI. Fr. Michael Sopocko was a special apostle of Divine Mercy who proclaimed its message to the world. This article presents the person and activities of Fr. Michael Sopocko by focusing on: 1 ) the source and the validity of worshiping Divine Mercy; 2) Fr. Sopocko's biblical and theological explanations of Divine Mercy; and 3) the image of the Merciful Jesus as the "manifestation" of Divine Mercy.

Key words: Divine Mercy, BI. Michael Sopocko; worship of Divine Mercy; Divine Mercy image; devotions to Divine Mercy.

Aware that he cannot make himself happy, man turns to God and asks for His Divine Mercy, which ensures man's eternal happiness. This is how man honors God and loves himself, since the essence of love is "every kind of seeking after the good and happiness, which is understood as 'eternal possession of the good,' or seeking after immortality." 1 In the $20^{\text {th }}$ century, Fr. Michael Sopocko was a priest and theologian especially involved in substantiating and spreading the cult of Divine Mercy. ${ }^{2}$ His religious involvement and academic research as well as the involvement of many other people in interpreting and substantiating worship of Divine Mercy is an expression of faith in this Truth as well as an expression of the needs of the times-sensus fidelium.

W. Stróżewski, Istnienie i wartość, Cracow 1981, pg. 163.

See H. Ciereszko, Ksiadz Michat Sopoćko Apostoł Miłosierdzia Bożego, Wyd. WAM, Cracow 2004; Ibid, Życie i działalność Księdza Michała Sopoćki (18881975). Petna biografia Apostoła Miłosierdzia Bożego, Wyd. WAM, Cracow 2006. 
Bl. Michael Sopocko

These needs made the actual development of Divine Mercy possible by spurring individuals to determine how Divine Mercy is religiously relevant and how it can be applied morally to the lives of the faithful. By drawing on sources such as the publications of Bl. Fr. Michael Sopocko, bibliographic texts, and St. Faustina Kowalska's writings, this article sheds light on the person of Bl. Fr. Michael Sopocko, who played such a key role in the history and development of the cult of Divine Mercy in the $20^{\text {th }}$ century.

\section{The Origin and Timeliness of Divine Mercy}

The new impetus to spread devotion to Divine Mercy in the early $20^{\text {th }}$ century is clearly evident in the private revelations of St. (Helena) Maria Faustina Kowalska-a Polish nun from the Congregation of the Sisters of Our Lady of Mercy to whom Jesus appeared and spoke. ${ }^{3}$ In St. Faustina's private revelations, Christ commanded her to do three things: 1) have an image of Divine Mercy (the Most Merciful Savior) painted; 2) write down the Divine Mercy prayers that He dictated to her; and 3) establish the Feast of Divine Mercy on the first Sunday after Easter.

Fr. Sopocko was a professor in the Theology Department at the Stefan Batory University as well as the Metropolitan Major Seminary in Vilnius. Later, in 1947, he became a professor at the Archdiocesan Major Seminary in Bialystok. ${ }^{4}$ While St. Faustina lived in Vilnius, Bl.

3 Helena Kowalska, otherwise known as Sr. Faustina in religious life, was born on August 25, 1905 in Glogowiec. She died in the opinion of holiness on October 5, 1928 in the convent of St. Joseph in Lagiewniki, near Cracow. From a very early age, Helena was very pious and prudent. When she was 20 years old, she entered the Congregation of the Sisters of Our Lady of Mercy. On April 30, 1933, Sr. Faustina made her perpetual profession of vows and served in convents in Warsaw, Plock, Walendow, Vilnius, and Lagiewniki. Sr. Faustina was prudent, had good common sense, and was endowed with a mature imagination. She experienced private revelations of Jesus, which she recorded in a diary after she was told to do so by her spiritual director, Fr. Michael Sopocko who resided in Vilnius. This diary was published under the title The Diary of Sister Faustina Kowalska from the Congregation of the Sisters of Our Lady of Mercy and published by the Pallotinian Priests, in Dolina Miłosierdzia Bożego, Ośrodek Naukowo-Badawczy, Częstochowa 1965.

Michael Sopocko was born on November 1, 1888 on a farmstead in Juszewszczyzna in the district of Oszmiana (now located in Belarus). Initially, he studied at the parish school in Valozhyn and then at the public school is Zabrzez. In 1906, Michael graduated from the Municipal School in Ashmyany. For three years, he worked as a teacher, and then in 1910, he entered the seminary in Vilnius. After he completed his seminary studies, he was ordained on June 15, 1914. As a priest, he was appointed parochial vicar of the parish in Taboryszki, 
Fr. Michael Sopocko served as her spiritual director. It was to him that she confided her revelations, Jesus' demands, and everything that she experienced. St. Faustina's revelations spurred Fr. Sopocko to become Bl. Michael Sopocko more deeply interested in devotion to Divine Mercy. Consequently, he sought to justify the existence and theology of the devotion by looking at Scripture, the teachings of the Church Fathers, and the writings of well-known theologians such as St. Thomas Aquinas. Fr. Sopocko found that worship of Divine Mercy was expressed the liturgy of the Church. While conducting his own research, Fr. Michael Sopocko began to spread devotion to Divine Mercy. Thanks to Fr. Sopocko's efforts and to the financial help that he received, the artist Eugeniusz Kazimierowski painted the first image of the Most Merciful Redeemer according to Sr. Faustina's instructions in Vilnius in 1934. Fr. Michael Sopocko also compiled and distributed the prayers to Divine Mercy—the Most Merciful Redeemer ${ }^{5}$ —on the First Sunday after Easter.

where he served until the end of the World War I. In November 1918, he enrolled in the Faculty of Theology at the University of Warsaw. However, the university had to close due to the war, and Fr. Sopocko suspended his studies. He was then appointed chaplain in the Polish Army. In this role, he organized field hospitals and ministered pastorally among the soldiers. During this time, he also resumed his studies at the Department of Theology and at the Major State Institute of Pedagogy. At the Bishop of Vilnius' request, Fr. Sopocko was transferred to Vilnius and appointed a garrison parish priest for the Polish Army. Fulfilling this role, Fr. Sopocko also led the Catholic Youth Union. In 1926, Fr. Sopocko obtained his doctorate in moral theology; in 1934, he received his habilitation. During this time, he also served as the spiritual father in the Metropolitan Seminary in Vilnius as well as a professor of pastoral theology in the Department of Theology of Stefan Batory University in Vilnius. In addition to his work in the seminary and at the university, he served as a spiritual director for the Congregation of the Sisters of Our Lady of Divine Mercy. As Sr. Faustina Kowalska's confessor, he was involved in spreading the message of and devotion to Divine Mercy. During World War II, Fr. Sopocko was sought out by the occupying forces and, therefore, had to go into hiding in Rudnik Forest. After the war, Archbishop R. Jalbrzykowski appointed Fr. Sopocko to work in the Seminary in Bialystok in 1947. Fr. Sopocko constantly worked to spread devotion to Divine Mercy by studying the theological background and foundations of the devotion. In 1964, he retired due to his health. Nevertheless, he continued his academic and pastoral work and spread devotion to Divine Mercy until the very end of his life. He died in the opinion of holiness on February 15, 1975 in Bialystok, where he was buried in the parish cemetery. He was declared Blessed at the Sanctuary of Divine Mercy in Bialystok on September 28, 2008. See H. Ciereszko, Życie i działalność Księdza Michała Sopoćki (1888-1975). Petna biografia Apostota Miłosierdzia Bożego, Wyd. WAM, Cracow 2006; Ibid, Ksiądz Michat Sopoćko. Apostot Miłosierdzia Bożego, Wyd. WAM, Cracow 2004. 
Bl. Michael Sopocko

Since Fr. Sopocko propagated devotion to Divine Mercy in three ways: through the image of the Merciful Jesus, through the Feast of Divine Mercy, and through prayers to Divine Mercy, each of which was in accordance with Sr. Faustina's revelations, the message of Divine Mercy spread very quickly throughout the entire world. ${ }^{6}$

Although devotion to Divine Mercy became more and more popular among the faithful, both theologians and Church authorities were initially opposed to the devotion. Because the devotion arose from Sr. Faustina's private revelations, the Sacred Congregation of the Holy Office prohibited spreading this devotion in the three ways mentioned above in 1958. Fr. Sopocko strove to respond to the difficulties he encountered regarding the Divine Mercy devotion by studying the topic intensely and substantiating the devotion through theological and patristic texts. He continually published new documents on this topic, including articles in theological journals as well as separate dogmatic and liturgical treatises. ${ }^{7}$ Fr. Michael Sopocko was the forerunner and apostle of devotion to Divine Mercy in our times. He also inspired other theologians to reflect on and study this topic. Fr. Sopocko's reflections and opinions in this regard continue to inspire others to become interested in this subject today.

Christ-the Most Merciful Redeemer. It is for this reason that "Divine Mercy" is written using capital letters and the terms are used interchangeably. It was on the basis of Pope Pius XI's encyclical that Fr. Sopocko petitioned to have the Feast of Divine Mercy established.

$6 \quad$ The occupation of Poland that occurred during World War II contributed to the popularization of this devotion outside of Poland. Soldiers and refugees of war willingly turned to Divine Mercy and shared with each other the prayers and images of the Merciful Redeemer. Fr. Jozef Jarzebowski was a Marian priest who escaped from Vilnius (which the Russian forces occupied) to the United States in 1941, bring with him the Latin treatise De Misericordia Dei deque Eiusdem festo instituendo that Fr. Sopocko had written and entrusted to him. In the United States and with the help of the Marians, Fr. J. Jarzebowski printed this treatise and began to spread devotion to Divine Mercy by distributing the Divine Mercy images and prayers. Fr. Jarzebowski's memoirs from his escape from Vilnius through Japan to the United States are published in Fr. J. Chróściechowski's work. See J. Chróściechowski,Miłosierdzie Bożenadziejąludzkości(mimeogram), issue by the Congregation of the Marians, Fawley Court Henley-on-Thomes, Oxon 1971, pgs. 81-95; Historia nabożeństwa do Miłosierdzia Bożego w naszych czasach, Rome 1973, pgs. 9-28.

7 Fr. Michael Sopocko wrote around 50 publications (books, articles, and papers) on Divine Mercy. In 1958, the Holy See decided to compile all of these publications into a 4-volume work entitled The Mercy of God in His Works, in which Fr. Sopocko did not refer to Sr. Faustina's visions. 
Devotion to Divine Mercy, which began during the first half of the $20^{\text {th }}$ century, has continued to develop and is a more recent form of religious devotion in the Catholic Church today. St. Faustina KowalBl. Michael Sopocko ska's private revelations confirmed the modern world's need for Divine Mercy, and Bl. Michael Sopocko was the one who presented this devotion to the world. The situation in which modern man finds himself and Sr. Faustina's private revelations reveal that Divine Mercy is the fundamental — and indeed the only-plane on which man encounters God during his earthly pilgrimage. For in eternity, meaning "the eschatological fulfillment[,] mercy will be revealed as love, while in temporality, meaning in human history, which is at the same time the history of sin and death, love must be revealed above all as mercy and must also be actualized as mercy." 8 Awareness of the power of Divine Mercy as well as man's absolute dependence on the Merciful Father make it such that "at no time and in no historical period-especially at a moment as critical as our own-can the Church forget the prayer that is a cry for the mercy of God amid the many forms of evil which weigh upon and threaten humanity."

People are generally aware of the forms that evil has been taking on in the world today. To point out and acknowledge these evils is not, however, an attempt to demonize the reality of the modern world, but rather a careful attempt to look critically and responsibly at reality.

Modern man often anxiously wonders about the solution to the terrible tensions which have built up in the world and which entangle humanity. And if at times he lacks the courage to utter the word 'mercy,' or if in his conscience empty of religious content he does not find the equivalent, so much greater is the need for the Church to utter this word, not only in her own name but also in the name of all the men and women of our time. ${ }^{10}$

The Church is entrusted with the task to speak of God's mercy especially to those who believe that turning to Divine Mercy is an "insult" to their dignity. For, such individuals have been beguiled by false ideas of "absolute humanism," which perceives the human person as an absolute and self-sufficient being. According to absolute humanists, God is only an "idea" created by weak people who have given up their ability to think. Humanists assert that "one cannot be a true person

\footnotetext{
$8 \quad$ John Paul II, Dives in Misericordia, 8.

9 Ibid, 15.

$10 \quad$ Ibid.
} 
Bl. Michael Sopocko

if one kneels before any other individual." ${ }^{11}$ In reality, the opposite is true, as the Polish poet Cyprian Norwid states in the well-known expression: "Humanity deprived of divinity betrays itself." Many modern individuals who ignore or disrespect God "betray themselves." Appealing to Divine Mercy is the Church's

fundamental [...] right and duty towards God and towards humanity. The more the human conscience succumbs to secularization, loses its sense of the very meaning of the word 'mercy,' moves away from God and distances itself from the mystery of mercy, the more the Church has the right and the duty to appeal to the God of mercy 'with loud cries.' ${ }^{12}$

\section{Fr. Sopocko's Biblical and Theological Substantiations for Devotion to Divine Mercy}

Bl. Michael Sopocko indicated that devotion to Divine Mercy is based on Revelation and has dogmatic foundations:

Devotion to Divine Mercy or the Most Merciful Christ is not at all new because its dogmatic basis essentially points to Revelation, where the Savior says: 'just as your Father is merciful' (Lk 6:36); in the expression 'So let us confidently approach the throne of grace to receive mercy' (Hebrews 4:16); and also in this often repeated appeal in the Psalms: 'Give thanks to the Lord, who is good, whose mercy endures forever' (Ps 105:1, 106: 1 ; 135, etc). ${ }^{13}$

Devotion to Divine Mercy is rooted in the truths of the faith regarding the Incarnation of the Son of God, Redemption, and the Sanctification of God's people toward "whom God's merciful love is the greatest."14

According to Bl. Michael Sopocko, the mercies that flow from the Incarnation are judged according to: a) the sublimity of the gift, b) the way in which the gift is given, and c) the effects that flow from it. ${ }^{15}$ Following the Church's teaching, Bl. Michael Sopocko asserted:

$11 \quad$ J. Mirewicz, Spotkania i dialogi, London 1980, pg. 21.

12 John Paul II, Dives im Misericordia, 15. See. J. Zabielski, Mitosierdzie chrześcijańskie wspótcześnie odczytane, "Studia Teologiczne," 9(1991), pgs. 97-119.

M. Sopoćko, O święto Najmiłosierniejszego Zbawiciela, Poznan 1947, pgs. 30.

W. Granat, Podstawy teologiczne kultu Miłosierdzia Bożego, in "Powołanie człowieka," vol. 2, Poznan 1972, pgs. 120-129.

See M. Sopoćko, Miłosierdzie Boga $w$ dziełach Jego, vol. 1, Rome - Paris - London 1962, pg. 37. Abbreviated hereafter as MB 1. 
In Christ there are two natures with all of their qualities: the divine nature and the human nature, which come together in the one Divine Person and constitute both God and Man. Everything that belongs to the Divine Son as God also belongs to Him as Man, and that which belongs to him as Man, He imparts to Himself as God. ${ }^{16}$

According to Bl. Michael Sopocko, the effects that flow from the Incarnation, "which last and will continue to last forever," are the special basis for the preferential and the merciful benefits of the Incarnation. ${ }^{17}$ In Fr. Sopocko's opinion, Mary's close relationship with the Trinity through the Incarnation is the basis for all graces and privileges that she received as well as the power with which she can now assist us. "Mary becomes our mother in a supernatural sense through Jesus because, since she gave birth to Jesus, she also gives birth to us into supernatural life through Him." ${ }^{18}$ According to Bl. Michael Sopocko, after Mary the Mother of Mercy, all people receive the merciful effects of the Incarnation because "the human race is elevated to an inexpressible dignity through the Incarnation." 19 Fr. Michael extends the merciful effects of the Incarnation not only to the entire human race, but also to all of creation; for, "[the Incarnation] is the completion, fulfillment, and perfection of the entire universe." 20

The effects of Redemption also manifest the fact and source of Divine Mercy. "Christ has reconciled us to God in his blood," explained Bl. Michael Sopocko, "[...] By this same holy passion and death on the cross, Christ justified us, meaning He obtained for us a share in this infinite treasure through His own suffering." ${ }^{21}$ Fr. Michael Sopocko explained that Christ as the Redeemer of the human race is the King, High Priest, and Teacher. Since the purpose of Christ's coming was to establish the Kingdom of God, then the Lord Jesus Christ as King ransomed us,

which had to have been obtained first, since the king of darkness reigned supreme. The Savior struggled with him during His own time in the desert; He conquered him, drove him out of those whom he possessed. [The Lord] fell under the weight of the cross, rose from the dead,

$16 \quad$ MB 1, pgs. 39-40. Por. M. Sopoćko, De Misericordia Dei, deque Eiusdem festo instituendo, op. cit., pg. 42.

$17 \quad$ MB 1, pg. 46.

18 Ibid.

19 Ibid, pgs. 48-49.

20 Ibid, pg. 49.

21 M. Sopoćko, Miłosierdzie Boga $w$ dziełach Jego, vol. 2, Rome - Paris - London 1962, pg. 7. Abbreviated hereafter as MB 2. Por. Pius XII, Haurietis aquas. 
Bl. Michael Sopocko

and sits at the right hand of the Father. The prince of this world was cast out at the moment that Christ was lifted up on the Cross. Jesus' passion, then, is His ascension to the throne..$^{22}$

Mary participated in the work of Redemption, and this participation is expressed in Her twofold motherhood as the Mother of Christ and our Mother. For these two reasons, Mary deserves to be called Mother of Mercy ${ }^{23}$ Christ's testament from the cross, through which God's particular mercy is shown, arises from the mutual love that existed between Mother and Son as well as the love that Christ has for all people:

Every Christian who looks upon the cross hears the words of Jesus crucified, 'Behold your Mother,' and knows that Mary really treats him as her son; She watches over her children and drives away the temptations of Satan, who 'is prowling around like a roaring lion looking for [someone] to devour" (1 Peter 5:8). ${ }^{24}$

Evidence for Divine Mercy in the salvific works of the Incarnation and Redemption has not been exhausted. For, God continues to show His mercy in the Church. In this regard, "All of the graces of the holy sacraments and sacramentals, indulgences and charisms, and the gifts and fruits of the Holy Spirit are unceasing streams of Mercy that flow out in the Church onto the faithful." ${ }^{25}$ Since "Christ came to earth for all people throughout the ages, Christ founded the Church out of his Mercy [...] The Church is the mystical Christ. Because of this, no one approaches the Father except through Christ, and no one comes to Christ except through the Church." ${ }^{26}$ Bl. Michael Sopocko asserted that the Church participates in two different kinds of merciful activity: the sacramental-mystical and the ethical-ascetical. He explained this assertion in the following way: "In the Church, it is impossible to be holy without the sacraments, and one cannot approach the sacraments without striving for perfection." ${ }^{27}$ The Christian remains a sinner. In His mercy, God reaches out to sinners by establishing the sacrament

MB 1, pgs. 220-221.

See M. Sopoćko, Matka Miłosierdzia, "Homo Dei,” 25(1957), pgs. 900-901. Por. A. L. Krupa, Rola Maryijako Matki Miłosierdzia w planach Mitosierdzia Bożego, in "Powołanie człowieka," vol. 2, Poznań 1972, pgs. 217-237.

MB 2, pg. 171. Por. M. Sopoćko, Matka Miłosierdzia, art. cit., pg. 901.

M. Sopoćko, Miłosierdzie Boga w dziełach Jego, vol 3, Rome - Paris - London 1962, pg. 5. Hereafter abbreviated as MB 3.

MB 3, pg. 213.

Ibid, pg. 215. 
of Penance, which Fr. Sopocko calls “The Sacrament of Divine Mercy," or "toilsome baptism." 28 "In addition to the sacrament of Baptism, the sacrament of Penance reveals God's infinite mercy that lasts for all Bl. Michael Sopocko ages until the end of time." ${ }^{29}$

Man, whose sins are forgiven, is gifted still more with God's Mercy in the Eucharist-the Sacrament of the Altar. "If all of the holy sacraments are the actualization of Divine mercy, then the Most Holy Sacrament is the highest expression [of mercy]. In the Eucharist the Redeemer imparts not only His grace, but also gives His very self." 30 The Sacrament of the Eucharist

is closely connected with the sacrament of the Priesthood, which was instituted at the same time as the Holy Eucharist on Holy Thursday. Infinite Divine Mercy is revealed in the sacrament of the Priesthood, too, to all people and primarily to all priests who [Christ] has chosen not because of their merits, but only because of His mercy."

Three priestly functions-sacrifice, prayer, and conferring the sacraments and teaching - are the sources "from which Divine Mercy flows out onto all people."31

In the Sacrament of Marriage, God's merciful love flows out onto both of the spouses and the entire human community. Sacramental marriage is also a manifestation of God's mercy on society, the state, and all mankind because the entire human community is based on the family. ${ }^{32}$ The sacrament of the Anointing of the Sick, the effects of which often determine the salvation or condemnation of man, is the final sacramental source of Divine Mercy. In this regard, Fr. Sopocko wrote: "The moment of death is the most important to me. For this reason, to me the sacrament of the Last Rites is one of the greatest works of Divine Mercy." 33

28 See Ibid, pg. 221. Por. M. Sopoćko, Miłosierdzie Boże, Vilnius 1936, pgs. 14-15.

$29 \quad$ MB 3, pg. 223.

$30 \quad$ Ibid, pg. 229. The Second Vatican Council also defined the Eucharist as the "sacrament of mercy." See The Constitution on the Sacred Liturgy: Sacrosanctum Concilium, 47.

31 Ibid.

$32 \quad$ See MB 3, pgs. 239-240.

33 Ibid, pg. 244. Por. J. Zabielski, Miłosierdzie - „wielkie wołanie” człowieka i świata, "Czas Miłosierdzia,” 8(2001), no. 1(129), pg. 15. 
Bl. Michael

\section{The Image of the Most Merciful Savior as} a "Manifestation" of Divine Mercy

The Church's external religious devotion takes on different forms through which the faithful worship God. ${ }^{34} \mathrm{Bl}$. Michael Sopocko set forth three forms of Divine Mercy devotion: the image of the Most Merciful Redeemer (Divine Mercy), a separate Feast of Divine Mercy, and prayers to Divine Mercy. These three forms of devotion can be found in the revelations of St. Faustina Kowalska who "the Lord chose to be His apostle of Mercy and to whom He gave two concrete tasks: to have an image of the Most Merciful Redeemer painted and to establish the Feast of Divine Mercy on the first Sunday after Easter." 35 Jesus also bid her to write down the prayers to Divine Mercy, which the $\mathrm{He}$ Himself dictated to her. ${ }^{36}$

As Divine Mercy devotion evolved, devotion to the image of the Most Merciful Redeemer (commonly called the image of Divine Mercy) assumed a central place. This image played a decisive role in shaping and developing devotion to Divine Mercy. The origin of the image of the Most Merciful Savior can be found in Sr. Faustina's revelations concerning Divine Mercy. ${ }^{37}$ Sr. Faustina received the first revelation concerning the image on February 22, 1931 while she was staying in a convent in Plock. During this revelation, Jesus ordered that an image of Him as the Most Merciful Redeemer be painted:

In the evening, when I was in my cell, I saw the Lord Jesus clothed in a white garment. One hand [was] raised in the gesture of blessing, the other was touching the garment at the breast. From beneath the garment, slightly drawn aside at the breast, there were emanating two large rays, one red, the other pale. In silence I kept my gaze fixed on the Lord; my soul was struck with awe, but also with great joy. After a while, Jesus said to me, Paint an image according to the pattern you see, with the signature: Jesus, I trust in You. I desire that this image be venerated, first in your chapel, and [then] throughout the world. I promise that the soul that will venerate this image will not perish. I also promise victory over [its] enemies already here on

See Pius XII, Mediator Dei.

M. Sopoćko, Miłosierdzie Boże nadzieja ludzkości, Wrocław 1948, pg. 19.

Sr. Faustina's revelations inspired Bl. Fr. Michael Sopocko to spend much time reflecting on and studying Divine Mercy, the fruits of which were his numerous works and activities dedicated to spreading devotion to Divine Mercy. See the Archdiocese of Bialystok's Archives, S-4, -34. Hereafter abbreviated as AAB.

See M. Sopoćko, Miłosierdzie Boże nadzieja ludzkości, op. cit., pg. 19-21; AAB, S-34. 
earth, especially at the hour of death. I Myself will defend it as My own glory $[. .$.$] I desire that priests proclaim this great mercy of Mine$ towards souls of sinners. ${ }^{38}$

Bl. Michael Sopocko

These apparitions occurred several times both at the convent in Plock, later in Warsaw, and then in Vilnius on October 26, 1934. Sr. Faustina took Jesus' order literally and tried to paint the image herself. Her attempts, however, were futile. When she returned to Vilnius in 1933, Sr. Faustina confided this to her confessor, Fr. Sopocko, who

after investigating her condition and psychological health, and with the permission and advice of her superiors, asked the artist and painter E. Kazimierowski to paint the image according to Sr. Faustina's indications. He was more curious about what the image would look like than filled with faith in the truth of the apparitions. ${ }^{39}$

At Fr. Sopocko's request, the artist Eugeniusz Kazimierowski began painting the image of Divine Mercy. Sr. Faustina personally instructed him regarding what the image should look like. After working on the image for six months, Eugeniusz Kazimierowski finished the painting in July 1934. However, when Sr. Faustina complained that the image of Christ was not as beautiful as what she had seen in her vision, Jesus responded to her, saying that

'Not in the beauty of the color, nor of the brush lies the greatness of this image, but in My grace. ${ }^{40} \mathrm{He}$ also said: "My gaze from this image is like My gaze from the cross" 41 and that "I am offering people a vessel with which they are to keep coming for graces to the fountain of mercy. That vessel is the image with the signature: 'Jesus, I trust in You. ${ }^{, 42,43}$

The image that E. Kazimierowski painted according to Sr. Faustina's indications

presents Christ coming forward against a dark background and wearing a white robe and girded with a belt. His right hand is raised in a gesture of blessing, while his left hand is opening his robe near his Heart (which

38 Quoted in: M. Sopoćko, Miłosierdzie Boże nadziejąludzkości, op. cit., pgs. 19-20.

S. M. Faustina Kowalska, Diary: Divine Mercy in My Soul, 47-50.

M. Sopoćko, Miłosierdzie Boże nadzieją ludzkości, op. cit., pg. 21. See AAB-S-6, -34 .

40 Diary, 313.

41 Diary, 326.

42 M. Sopoćko, Miłosierdzie Boże nadzieja ludzkości, op. cit., pg. 21.

43 Diary, 327. 
Bl. Michael Sopocko

is not shown), from which two rays of light emanate (the one on the right is white, and the one on the left is red) in opposite directions. ${ }^{44}$

For a long time, the image painted by E. Kazimierowski remained unknown to many people. Without revealing the origin of the image, Fr. Sopocko placed it in the corridor of convent of the Bernardine Sisters located next to St. Michael's church in Vilnius where Fr. Sopocko was the rector. After some time, Sr. Faustina began to insist that the image be placed in a public location because Jesus Himself was demanding that of her. In April 1935, at Sr. Faustina's request and with the permission of the pastor of the Parish of Ostra Brama [the Bright Gate] in Vilnius, Fr. Sopocko placed the painting in the window of Ostra Brama as a decoration for the Easter Triduum, which was to take place in that location on the occasion of the end of the Jubilee Year of the Redemption. ${ }^{45}$ It was not until March 1937 that Fr. Sopocko decided to ask the Archbishop of Vilnius, Romuald Jalbrzykowski, to evaluate the image and give his permission to have the image hung in St. Michael's church. The Archdiocesan Commission approved the image and the first Sunday after Easter-April 4, 1937-was proposed as the day on which the Feast of Divine Mercy was to be celebrated. With the Archbishop's blessing, Fr. Michael Sopocko hung the image in St. Michael's church next to the main altar, but he never told anyone from where it came. From the very beginning, the image was very popular among the faithful: "When the lighting was good, the image had an influence on those who prayed before it; they requested several times that it be placed in the altar for the Corpus Christi procession." 46

During the occupation, devotion to Divine Mercy spread considerably. The occupiers were hostile to this devotion, and when they found out who was spreading it, they wanted to arrest Fr. Sopocko. He, however, hid, first from the Soviet Army in Lithuania, and then from the Germans in the forest near Jaszun where he stayed from March 2, 1942 until July 15, 1944 with the help of the Grey Ursuline Sisters. At that time, devotion to Divine Mercy became even more intense, even though the devotion had become distorted in some places where the

44

45

M. Sopoćko, Sprawa poprawności obrazu Miłosierdzia Bożego, (typescript), AAB-S-34.

The image hung there for three days, from April 26-28, 1935 (Friday, Saturday, and the First Sunday after Easter, which was designated as the day on which the Feast of Divine Mercy should be celebrated). The image was then transferred to its former place in the convent of Bernardine nuns. See AAB-S-4.

AAB-S-4. On April 15, 1938, Fr. Sopocko presented a copy of this painting to Archbishop R. Jalbrzykowski, who was leaving for Rome, with the request that help in the matter of establishing the Feast of Divine Mercy. AAB-S-6. 
image was treated as a kind of fetish. ${ }^{47}$ In 1941, a special appointed commission of art historians assessed the painting. After carefully inspecting it, the commission ruled: "The image is artistically rendered Bl. Michael Sopocko and is a valuable achievement in contemporary religious art." 48

After World War II, Poland's borders had changed. As a result, the Seminary and the Archdiocesan Curia were transferred from Vilnius to Bialystok. In addition, Archbishop Jalbrzykowski summoned Fr. Sopocko to Bialystok to be a lecturer at the Seminary in 1947. He wrote: "I did not take the image with me and, after some time, it was found in a church in Nowa Ruda near Grodno." ${ }^{49}$ This is where the history of the image of the Most Merciful Savior painted by E. Kazimierowski according to Sr. Faustina's indications is interrupted.

After Sr. Faustina's death on October 5, 1938, and particularly after the war, devotion to Divine Mercy began to spread. Because E. Kazimierowski's painting was unavailable, a new image was painted. The order to which Sr. Faustina belonged, the Congregation of the Sisters of Our Lady of Mercy, and especially those sisters who lived in Lagiewniki where Sr. Faustina was buried, became particularly interested in the devotion. These sisters and Fr. Andrasz instructed Mr. Hyla to paint the image of the Most Merciful Savior using, as Fr. Sopocko writes,

a very poor reproduction of the image painted by Lucja Balzukiewiczowna for a brochure with prayers [...]. Desiring to fix the poor and incorrect reproduction, those who requested the image gave the artist indications, but not knowing the details of this image, they themselves were unable to provide Mr. Hyla with the correct indications. [As a result, Hyla] painted Christ against a background of flowers with his right hand raised high above him in an arch as he looked wistfully (or rather piercingly) at the viewer. ${ }^{50}$

According to Fr. Michael Sopocko, the image of the Most Merciful Redeemer fits precisely into the liturgy of the entire liturgical year. However, it corresponds most fittingly to the liturgy that falls on the Second Sunday of Easter, which Jesus designated as the Feast of Divine Mercy. A characteristic feature of this image is its inscription: "Jesus, I trust in You." Fr. Sopocko saw that trust should be our response to Christ's call: "[Take] courage, I have conquered the world"

\footnotetext{
$47 \quad$ See Ibid.

$48 \quad$ AAB-S-4.

49 Ibid. 
Bl. Michael Sopocko

(John 16:33). ${ }^{51}$ The image of the Most Merciful Redeemer follows the norms prescribed by the Church. The Main Commission of the Conference of Polish Bishops approved the image for public veneration. In his efforts to share devotion to Divine Mercy, Fr. Michael Sopocko believed that the painting was very important and considered it one of the primary forms of devotion. For this reason, he provided deep theological substantiations for the existence of the image, and he demonstrated both the need for and the effectiveness of devotion to it..$^{52}$ Religious devotion to the image of the Most Merciful Savior has continued to spread throughout the world not due to special propaganda, but rather because of modern man's spiritual needs. Needless to say, the image has had an extraordinary effect on many people, including the conversion of sinners and the granting of many other graces. This image can be found in many churches where the faithful pray before it and light votive candles, entrusting to Christ the Most Merciful Savior all of their concerns and needs.

\section{BŁOGOSŁAWIONY MICHAŁ SOPOĆKO : PRZYBLIŻAJĄCY TAJEMNICĘ BOŻEGO MIŁOSIERDZIA}

Gwarantem ludzkiej szczęśliwości jest Boże Miłosierdzie. W ostatnim stuleciu szczególnym Apostołem Bożego Miłosierdzia i osobą zaangażowaną w Jego przybliżenie światu był bł. ks. Michał Sopoćko. Ukazując jego postać i aktywność w tym względzie w niniejszych analizach skupiono się na następujących zagadnieniach: 1. Geneza i aktualność kultu Bożego Miłosierdzia; 2. Biblijno-teologiczne uzasadnienie kultu Bożego Miłosierdzia w ujęciu ks. Michała Sopoćki; 3. Obraz Najmiłosierniejszego Zbawiciela jako „objawienie” Bożego Miłosierdzia.

Słowa kluczowe: Boże Miłosierdzie, bł. ks. Michał Sopoćko, kult Bożego Miłosierdzia, obraz Najmiłosierniejszego Zbawiciela, formy kultu Bożego Miłosierdzia.

$51 \quad$ See M. Sopoćko, J. Chróściechowski, Domine miserere nobis, op. cit., pg. 45.

52 According to St. Faustina's revelations, Jesus made two promises regarding this image: "I promise that the soul that will venerate this image will not perish. I also promise victory over its enemies already here on earth, especially at the hour of death. I myself will defend it as My own glory [...] I desire that priests proclaim this great mercy of Mine toward the souls of sinners. Let no sinner be afraid to approach Me" (Diary 48, 50). M. Sopoćko, Miłosierdzie Boże nadzieja ludzkości, Wroclaw 1948, pg. 20. 


\section{Bibliography:}

1. Ciereszko H., Ksiądz Michał Sopoćko Apostoł Miłosierdzia Bożego, Cracow 2004.

2. Ciereszko H., Życie i działalność Księdza Michała Sopoćki (1888-1975). Petna biografia Apostoła Miłosierdzia Bożego, Cracow 2006.

3. John Paul II, Encyclical: Dives in misericordia.

4. Granat W., Podstawy teologiczne kultu Miłosierdzia Bożego, in "Powołanie człowieka," vol. 2, Poznan 1972, pgs. 120-129.

5. Krupa A. L., Rola Maryi jako Matki Mitosierdzia w planach Mitosierdzia Bożego, in "Powołanie Człowieka," Poznan 1972, pgs. 217-237.

6. Mirewicz J., Spotkania i dialogi, London 1980.

7. Pius XII, Encyclical: Mediator Dei.

8. Second Vatican Council, Constitution on the Sacred Liturgy: Sacrosanctum Concilium.

9. Sopoćko M., Miłosierdzie Boga w dziełach Jego, vols. 1-3, Rome - Paris London, 1962.

10. Sopoćko M., O święto Najmiłosierniejszego Zbawiciela, Poznan 1947.

11. Sopoćko M., Miłosierdzie Boże, Vilnius 1936.

12. Sopoćko M., Sprawa poprawności obrazu Miłosierdzia Bożego [typescript], "Archiwum Archidiecezji Białostockiej" [abbreviated as AAB], S-34.

13. Sopoćko M., Mitosierdzie Boże nadzieja ludzkości, Wroclaw 1948.

14. Sopoćko M., De Misericordia Dei, deque Eiusdem festo instituendo, Varsavia 1947.

15. Sopoćko M., O święto Najmiłosierniejszego Zbawiciela, Poznan 1947.

16. Sopoćko M., Matka Mitosierdzia, "Homo Dei", 25, 1957, pgs. 900-901.

17. Sopoćko M., Chróściechowski J., Domine miserere nobis, London 1967.

18. Stróżewski W., Istnienie i wartość, Cracow 1981.

19. Zabielski J., Miłosierdzie chrześcijańskie wspótcześnie odczytane, "Studia Teologiczne," 9(1991), pgs. 97-119.

20. Zabielski J., Miłosierdzie - "wielkie wotanie" człowieka i świata, "Czas Miłosierdzia,” 8(2001), no. 1(129), pg. 15. 